\title{
THE EFFECTS OF OUTCOME FROM HEALTH CARE EXPENDITURE IN INDIA: A TIME-SERIES ANALYSIS
}

\author{
Ashok Bhukta \\ Ph.D. Scholar \\ Department of Economics, \\ Berhampur University
}

\author{
Prof. Sudhakar Patra \\ Professor \\ Department of Economics, \\ Berhampur University
}

Article DOI: $\underline{\text { https://doi.org/10.36713/epra6899 }}$

DOI No: 10.36713/epra6899

\begin{abstract}
The effects of outcome from Health Care Expenditure in India: A Time-Series Analysis is the objective of this article with reveals that the level of health expenditure on various schemes and indicates is a little bit low. It can be suggested that some relevant measures need to be taken towards the improvement of the role of government for providing proper schemes related to the health sector and increments budgetary allocation at both national and states governments' level. Moreover in India, many more problems arise in government hospital scheduled at poor physical or health care facilities in medical supplies, ineffective leadership and faculty with staff problems. Regarding health care facilities in a private hospital, it is not there rather many modern facilities with proper staff working regularly are available. In view of the above, the present article analyses the trend and pattern of health care expenditure in India. This article carries some statistical methodologies for the analysis like regression and some statistical tests.
\end{abstract}

KEY WORDS: Health care Sector, Public \& Private Healthcare Expenditure, Regression, Budgetary allocation.

\section{INTRODUCTION}

Health expenditure refers to the amount defrayed towards health care by the Central, State and Union Territory governments. It excludes expenditure by local bodies, public sector enterprises and autonomous and semi-autonomous institution. The different components of Despite the gradual stepping up of Union Budget allocation for Health \& Family Welfare since 2005-06, Centre's expenditure on health still accounts for a very small magnitude as compared to the overall level of public spending on health recognized as necessary for the country. State Government In the government sector, the provision of health care is the responsibility of the State government. The states account for over 90 per cent of the aggregate health expenditure of central and state governments. Their share taken together spending has increased in the past years.

Involvement of the central government in states budget is confined mainly to family planning and certainly centrally sponsored disease control programmes. National programme on control of leprosy, immunization scheme for children and ICDS are some of the examples of centrally sponsored schemes. But such uniformity is absent in the case of state's expenditure on their areas of responsibility such as medical relief, public health, medical education, water supply and sanitation and states own schemes in nutrition. The ability of the states to make a sufficient level of allocation of money to a different component of health depends on some factors. Thus, health is affected by a host of factors Infant Mortality Rate (IMR), Life Expectancy at Birth (LEB), Crude Death Rate (CDR), Crude Birth Rate (CBR), No. of Hospital Serving per '000 of population, No. of Hospital beds Serving per ' 000 of population Doctors serving per ' 000 of population, Literacy Rate and Sex Ratio. This chapter attempts to study the relations between major indicators of health status with Public health expenditure current prices. To analysis, the 
ISSN (Online): 2455-3662

EPRA International Journal of Multidisciplinary Research (IJMR) - Peer Reviewed Journal

Volume: 7 | Issue: 4 | April 2021|| Journal DOI: 10.36713/epra2013 || SJIF Impact Factor 2021: 8.047 || ISI Value: 1.188

relationship, simple regression has been applied by taking various health status indicators as a function of public health expenditure current prices (PHECP).

Hypothesis to be tested

Based on the problem statements, the objective of the study, the following Null hypotheses have been framed for empirical verification.

Hypothesis-1: Null hypothesis: - $\mathbf{H}_{0}$ : Flow of health expenditure in India shows a positive trend over the period from 1992-2020.

Alternative hypothesis: - $\mathbf{H}_{\mathbf{1}}$ : Health expenditure in India is not increasing over the period from 1992-2020. Hypothesis-2: Null hypothesis: $-\mathbf{H}_{\mathbf{0}}$ : There is no significant long-run relationship between health care expenditure at the current price and IMR.
Alternative hypothesis: - $\mathbf{H}_{\mathbf{1}}$ : There is a significant long-run relationship between health care expenditure at the current price and IMR.

If the p-value is more than $5 \%$ we cannot reject the null rather accept null and p-value less than 5 $\%$ only we can reject null and accept the alternative hypotheses in our model.

Health Care Expenditure in India (Served per '000 of the population)

Year-wise public health expenditure at the current price with health status in India has been shown in the following table.

Table-1 Health Care Expenditure in India (Served per '000 of the population)

\begin{tabular}{|c|c|c|c|c|c|c|c|c|c|c|}
\hline Year & PHECP & $\begin{array}{c}\text { Crude } \\
\text { Death } \\
\text { Rate }\end{array}$ & $\begin{array}{c}\text { Crude } \\
\text { Birth } \\
\text { Rate }\end{array}$ & $\begin{array}{c}\text { Life } \\
\text { Expectancy } \\
\text { at Birth }\end{array}$ & $\begin{array}{c}\text { Literacy } \\
\text { Rate }\end{array}$ & $\begin{array}{c}\text { Infant } \\
\text { Mortality } \\
\text { Rate }\end{array}$ & $\begin{array}{c}\text { Sex } \\
\text { Ratio }\end{array}$ & Hospitals & $\begin{array}{l}\text { Hospital } \\
\text { beds }\end{array}$ & Doctors \\
\hline 1992 & 17.65 & 10.10 & 29.20 & 58.85 & 72.35 & 84.30 & 2.02 & 0.11 & 0.79 & 0.22 \\
\hline 1993 & 17.88 & 9.30 & 28.70 & 59.35 & 72.85 & 82.20 & 1.97 & 0.12 & 1.00 & 0.48 \\
\hline 1994 & 18.28 & 9.30 & 28.70 & 59.84 & 73.47 & 80.10 & 1.94 & 0.15 & 1.02 & 0.41 \\
\hline 1995 & 18.68 & 9.00 & 28.30 & 60.32 & 73.85 & 78.00 & 1.92 & 0.17 & 1.04 & 0.46 \\
\hline 1996 & 18.99 & 9.00 & 27.50 & 60.78 & 74.35 & 75.80 & 1.90 & 0.19 & 1.08 & 0.47 \\
\hline 1997 & 20.25 & 8.90 & 27.20 & 61.23 & 74.95 & 73.60 & 1.87 & 0.25 & 1.10 & 0.49 \\
\hline 1998 & 17.98 & 9.00 & 26.50 & 61.67 & 75.87 & 71.30 & 1.84 & 0.12 & 1.12 & 0.50 \\
\hline 1999 & 20.98 & 8.70 & 26.10 & 62.09 & 75.96 & 69.00 & 1.81 & 0.11 & 1.14 & 0.51 \\
\hline 2000 & 20.68 & 8.50 & 25.80 & 62.51 & 76.12 & 66.70 & 1.77 & 0.12 & 1.17 & 0.52 \\
\hline 2001 & 18.87 & 8.40 & 25.40 & 62.91 & 76.43 & 64.40 & 1.73 & 0.15 & 1.18 & 0.53 \\
\hline 2002 & 18.16 & 8.10 & 25.00 & 63.30 & 77.56 & 62.20 & 1.69 & 0.17 & 1.12 & 0.54 \\
\hline 2003 & 18.71 & 8.00 & 24.80 & 63.70 & 78.58 & 60.00 & 1.65 & 0.12 & 0.90 & 0.56 \\
\hline 2004 & 17.98 & 7.50 & 24.10 & 64.10 & 78.97 & 57.80 & 1.62 & 0.20 & 1.16 & 0.56 \\
\hline 2005 & 20.12 & 7.60 & 23.80 & 64.50 & 80.68 & 55.70 & 1.58 & 0.23 & 1.29 & 0.57 \\
\hline 2006 & 20.51 & 7.50 & 22.50 & 64.92 & 81.13 & 53.70 & 1.55 & 0.24 & 0.78 & 0.57 \\
\hline 2007 & 20.89 & 7.40 & 22.10 & 65.35 & 81.98 & 51.60 & 1.51 & 0.27 & 0.79 & 0.59 \\
\hline 2008 & 22.63 & 7.40 & 21.80 & 65.79 & 83.71 & 49.40 & 1.46 & 0.28 & 0.81 & 0.60 \\
\hline 2009 & 25.61 & 7.30 & 21.60 & 66.24 & 84.25 & 47.30 & 1.41 & 0.23 & 0.86 & 0.61 \\
\hline 2010 & 26.21 & 7.20 & 21.40 & 66.69 & 85.56 & 45.10 & 1.35 & 0.25 & 0.87 & 0.62 \\
\hline 2011 & 28.87 & 7.10 & 21.00 & 67.13 & 86.14 & 43.00 & 1.29 & 0.11 & 0.99 & 0.66 \\
\hline 2012 & 27.98 & 7.00 & 20.80 & 67.55 & 87.27 & 40.90 & 1.23 & 0.21 & 1.11 & 0.74 \\
\hline 2013 & 23.07 & 7.00 & 20.40 & 67.93 & 87.69 & 38.80 & 1.18 & 0.11 & 1.22 & 0.70 \\
\hline 2014 & 23.66 & 6.70 & 19.25 & 68.29 & 88.37 & 36.90 & 1.15 & 0.11 & 1.17 & 0.72 \\
\hline 2015 & 25.64 & 6.50 & 18.94 & 68.61 & 88.45 & 34.90 & 1.12 & 0.30 & 1.05 & 0.72 \\
\hline 2016 & 26.84 & 6.40 & 18.64 & 68.90 & 89.86 & 33.10 & 1.09 & 0.29 & 1.15 & 0.74 \\
\hline 2017 & 27.13 & 6.44 & 18.33 & 69.17 & 90.46 & 31.40 & 1.06 & 0.30 & 0.53 & 0.76 \\
\hline 2018 & 27.78 & 6.48 & 18.02 & 69.42 & 91.66 & 29.70 & 1.04 & 0.29 & 0.55 & 0.78 \\
\hline 2019 & 28.52 & 6.58 & 17.81 & 69.12 & 91.89 & 28.30 & 1.02 & 0.35 & 0.82 & 0.86 \\
\hline 2020 & 27.13 & 6.77 & 17.79 & 68.54 & 91.94 & 27.38 & 1.00 & 0.37 & 1.18 & 0.98 \\
\hline Mean & 22.33 & 7.76 & 23.15 & 64.79 & 81.81 & 54.23 & 1.51 & 0.20 & 1.00 & 0.60 \\
\hline SD & 3.92 & 1.05 & 3.71 & 3.35 & 6.57 & 17.91 & 0.34 & 0.08 & 0.19 & 0.15 \\
\hline $\mathrm{CV}$ & 17.55 & 13.55 & 16.04 & 5.18 & 8.03 & 33.03 & 22.21 & 39.27 & 19.46 & 24.96 \\
\hline
\end{tabular}

Source: World Bank Database 
Table-1 the above table indicates the health care expenditure and status. It is visible the PHECP is increasing in trend from 1992 to 1997 after this it has been decreased for one year again increasing up to 2000. From 2002 to 2004 decreasing trend then after it is in the increasing trend up to 2012. After 2012 suddenly decreasing is there for one year. After 2013 the increasing trend is there up to 2020.

To identify and isolate the factors which were responsible for variations in health status and public health expenditure at current prices. The regression analysis has been applied to determine the relative contribution of different explanatory variables on the dependent variable. The results of regression between indicators at dependent variable and public health expenditure at current prices (PHECP) as the independent variable for the year 1992 to 2020 as for the following regression equations.

\section{Methodology}

Following techniques were applied to analyze the data for achieving the desired objective. These techniques are discussed below: it is a statistical measure of the dispersion of data points in a data series around mean. It is calculated as under $\mathrm{CV}=\mathrm{SD} /$ Expected returns (Mean). It represented the ratio of the standard deviation to mean and it is a useful statistic for comparing the degree of Variation from one data series to another, even if the means drastically different from each other. In this analysis $\mathrm{CV}$ was calculated for measuring was found out. To identify and isolate the factors which were responsible for annual variations in health status and public health expenditure at current prices. The simple regression analysis has been applied to determine the relative contribution of different explanatory variables on the dependent variable and public health expenditure at current prices (PHECP) as the independent variable for the year 1992 to 2020 are given in the following regression equations.

\section{Data and definition of variables}

In the present chapter, an annual time series dataset covering the period 1992 to 2020 have been used. The choice of this period is based on data availability. The study sourced data from the World Bank database and regarding health status indicators and public health expenditure in India.

\section{The features or characteristics of the best regression Model}

- High R square value

- No serial Correlation in the residual

- No Heteroskedasticity in the residual
- Residuals are normally distributed

During the time of applying the model, all null hypotheses should be rejected to be a better model.

\section{Model Specification and Data Analysis}

Sex ratio is defined as the number of females per 1000 males in the population and is an important social indicator to measure the extent of prevailing equity between males and females in a society at a given point in time. Sex Ratio defined as the number of females per 1000 males in the 0-6 age group is a very vital indicator to check the abnormalities which are leading to an imbalanced sex ratio. If the sex ratio is improved only at birth then it would surely lead to an increase in the overall sex ratio. Sex ratio in the country has shown a declining trend since Census 1991. Sex ratio at country level was 945 in 1991, 927 in 2001 and has now declined to 919 in Census 2011.

\section{Sex Ratio}

Sex ratio, defined, as the number of females per thousand males, is an important health status indicator to measure the extent of prevailing equality between males and females in a society at a given point in time. The sex ratio in the country had always remained unfavourable to females. It was 940 in 2011. In 2020 , the sex ratio of the total population in India is 108.18 males per 100 females. There are 717.10 million males and 662.90 million females in India. The percentage of the female population is 48.04 per cent compared to 51.96 per cent male population. India has the highest numbers of exceeding the males' population of 54.20 million. India is at 189 th position out of 201 countries/territories in terms of female to male ratio. In India, the male to female ratio has increased from 104.40 in 1950 to a peak value of 108.47 in 2008 . This ratio is projected to decline at 103.36 in 2092. As per Census 2011, the Gender ratio of India is 943 females per 1000 males. India's Sex Ratio had improved by number 10 from 933 in 2001 to 943 in 2011. The Sex ratio has improved by numbers 3 and 29, respectively. In 1901, India had the highest sex ratio of 972.

A simple regression model of health status (i.e., sex ratio) is presented as follows:

$\mathrm{SR}=\boldsymbol{\alpha}+\boldsymbol{\beta} \mathrm{PHECP}+\boldsymbol{\epsilon}$

Whereas Sex ratio (SR) is the dependent variable of health status, Public health expenditure at the current price (PHECP) is a vector of independent variables influencing health status, $\alpha$ is intercept and $\beta$ is a vector coefficient of the independent variables. $€$ is the error term that is assumed to be normally distributed with zero mean and constant variance. The operational Regression model is specified Estimation Equation below: 
$\mathbf{S R}=\boldsymbol{\alpha}(3.21)+\boldsymbol{\beta}(-0.08) * \mathbf{P H E C P}+\boldsymbol{\epsilon}$

The ordinary least squares regression was used to examine the effect of public health expenditure at the current price on sex ratio while controlling other health correlates. The overall model was good since the pvalue for the F-statistic was 0.00 . This implies that at least one of the regression coefficients was not equal to Zero.

\section{Infant Mortality Rate}

The infant mortality rate is the number of deaths of children under one year of age per 1,000 live births. This rate is an important health status indicator for a country's health and standard of living; a low infant mortality rate indicates a high standard of healthcare. Causes of infant mortality include premature birth, sepsis or meningitis, sudden infant death syndrome, and pneumonia. Globally, the infant mortality rate has shrunk from 63 infant deaths per 1,000 live births to 27 since 1990 and is forecast to drop to 8 infant deaths per 1,000 live births by the year 2100. In 2019, the infant mortality rate in India was at about 28.3 deaths per 1,000 live births, a significant decrease from previous years.

A simple regression model of health status (i.e., Infant Mortality Rate) is presented as follows:

$\mathrm{IMR}=\alpha+\beta$ PHECP $+\epsilon$

The regression model is specified Estimation Equation with Substituted Coefficients below:

$\mathrm{IMR}=\boldsymbol{\alpha}(143.5)+\boldsymbol{\beta}(-4.00) *$ PHECP

\section{Life Expectancy at Birth}

The statistic shows the life expectancy at birth in India from 1992 to 2020. The average life expectancy at birth in India in 2020 was 69.27 years. Additionally, the total population of India has been steadily increasing. Regarding life expectancy, India is neither among the countries with the highest nor among those with the lowest life expectancy at birth. The majority of the Indian population is aged between 15 and 64 years, with only about 5 per cent being older than 64. Life expectancy in India was 69.27 in the year 2020 , and over the next 220 years, it has increased to almost 70. Between 1992 and 2020, life expectancy in India remained in the mid to low twenties, with the largest declines coming in the 1992s and 2020s; both of which were responsible for the deaths of up to six and seventeen million Indians respectively; From 1920 onwards, India's life expectancy has consistently increased, but it is still below the global average.

A simple regression model of health status (i.e., Life Expectancy at Birth) is presented as follows:

$\mathrm{LEB}=\boldsymbol{\alpha}+\boldsymbol{\beta}$ PHECP $+\boldsymbol{\epsilon}$

The regression model is specified Estimation Equation with Substituted Coefficients below:
Life Expectancy at Birth =

$\alpha(48.08)+\beta(0.75) *$ PHECP + €

\section{Crude Death Rate}

The statistic shows the death rate in India from 1992 to 2020 . In 2020, there were about 7.3 deaths per 1,000 inhabitants in India. In 2020, the crude death rate for India was 7.3 deaths per thousand populations. Over the last 50 years, the crude death rate of India was declining at a moderate rate to shrink from 16.73 deaths per thousand populations in 1971 to 7.19 deaths per thousand populations in 2020. The crude death rate (per 1,000 people) in India was reported at $7.23 \%$ in 2018 , according to the World Bank collection of development database indicators.

A simple regression model of health status (i.e., Crude Death Rate) is presented as follows:

$\mathrm{CDR}=\boldsymbol{\alpha}+\boldsymbol{\beta} \mathrm{PHECP}+\boldsymbol{\epsilon}$

The regression model is specified Estimation Equation with Substituted Coefficients below:

Crude Death Rate =

$\alpha(12.70)+\beta(-0.22) *$ PHECP + €

\section{Crude Birth Rate}

The birth rate for India in 2020 was 17.59 births per 1000 people, a $1.2 \%$ decline from 2019 . The birth rate for India in 2019 was 17.81 births per 1000 people, a $1.19 \%$ decline from 2018. The current birth rate for India in 2021 is 17.38 births per 1000 people, a $1.22 \%$ decline from 2020 . The birth rate for India in 2020 was 17.59 births per 1000 people, a $1.2 \%$ decline from 2019. The birth rate for India in 2019 was 17.81 births per 1000 people, a $1.19 \%$ decline from 2018. The birth rate for India in 2018 was 18.02 births per 1000 people, a $1.68 \%$ decline from 2017 . In 2020, the crude birth rate for India was 17.44 births per thousand populations. The crude birth rate of India fell gradually from 38.82 births per thousand populations in 1971 to 17.44 births per thousand populations in 2020 .

A simple regression model of health status (i.e., Crude Birth Rate) is presented as follows:

$\mathrm{CBR}=\boldsymbol{\alpha}+\boldsymbol{\beta}$ PHECP $+\epsilon$

The regression model is specified Estimation Equation with Substituted Coefficients below:

Crude Birth Rate $=$

$\alpha(41.60)+\beta(-0.83) *$ PHECP + $\epsilon$

Hospitals Served Per '000 population

A major problem with planning for the provision of medical facilities is the paucity of specific data, especially on private hospitals. Available data on government hospitals have been used here but it is clear even from basic research that it does not provide a true picture of the quality or quantity of health care in the country," the survey report said. In India, there were an estimated 69 thousand public and private sector 
hospitals in 2019, with the northern state of Uttar Pradesh possessing much more hospitals. By a large margin, private hospitals exceed the number public hospitals.

A simple regression model of health status (i.e., Hospital Served Per '000 people) is presented as follows:

HOSP $=\alpha+\beta$ PHECP $+\epsilon$

The regression model is specified Estimation Equation with Substituted Coefficients below:

Hospital Served Per '000 people =

$\alpha(-0.06)+\beta(0.01) * P H E C P+\epsilon$

Hospital Beds Served Per '000 population

Government supplementary hospitals have a larger bed capacity (over 500), while bed capacity in all private facilities surveyed is between 200 and 500. It was also found that the bed occupancy rate in government hospitals is very high (over 85\%). Depending on the season, occupancy varies, but during the winter, it stays on the lower side. During the summer monsoon season, however, and especially during outbreaks of malaria, dengue fever, and other diseases, the occupancy rate in general and medicine wards will exceed 200 per cent. The average occupancy rate in private hospitals ranges between 50-100 per cent. Government hospitals cater to a large section of lower-income group people. Many of them are covered under medical plans for the centre and state government workers. They also support critical patients from a range of socioeconomic backgrounds and nations. Private hospitals, on the other hand, charge a premium on their facilities. This brings a lot of pressure on government referral hospitals. The following table provides bed availability and bed occupancy rates of various referral hospitals sampled.

A simple regression model of health status (i.e., Hospital Beds Served Per '000 Peoples) is presented as follows:

$\mathrm{BEDS}=\alpha+\beta$ PHECP $+\epsilon$

The regression model is specified Estimation Equation with Substituted Coefficients below:

Hospital Beds Served Per '000 Peoples $=\alpha$ (1.33)

$+\beta(-0.01) *$ PHECP + $€$

\section{Doctors Served Per '000 Population}

An important indicator of health status is Doctors serving per ' 000 of population. To find out the increase in the number of doctors per ' 000 of the population served, the simple average growth rates have been worked out for all the three respective periods of the study. An increase in its growth rate signifies a better position of health services.

A simple regression model of health status (i.e., Doctors Served Per '000 people) is presented as follows:

$\mathrm{DRS}=\alpha+\beta$ PHECP $+\epsilon$

The regression model is specified Estimation Equation with Substituted Coefficients below:

Doctors Served Per '000 people $=$

$\alpha(-0.10)+\beta(0.03) *$ PHECP + €

Literacy Rate

Literacy is identified as anyone who can read and write in any language with understanding at the age of seven, according to census 2011. Literacy is defined as the ability to read but not write. Before 1991, children as young as five were automatically classified as illiterates in censuses. According to the results of the 2011 census, the country's literacy rate has increased. The country's literacy rate is 74.04 per cent, with males achieving 82.14 and females ranking 65.46. The literacy rate is defined as the percentage of people aged 15 and up who can read and write a brief, clear statement about their regular lifestyle. The literacy rate in India in 2018 was 74.37 per cent, rising 5.07 per cent from 2011. The literacy rate in India in 2011 was 69.30 per cent, rising 6.55 per cent from 2006. In 2006, India's literacy rate was 62.75 per cent, rising 1.74 per cent from 2001. The literacy rate in India in 2001 was 61.01 per cent, rising 12.79 per cent from 1991 .

A simple regression model of health status (i.e., Literacy Rate) is presented as follows:

LIT $=\alpha+\beta$ PHECP $+\epsilon$

The regression model is specified Estimation Equation with Substituted Coefficients below: Literacy Rate $=\alpha(47.92)+\beta(1.52) *$ PHECP $+€$ 
ISSN (Online): 2455-3662

EPRA International Journal of Multidisciplinary Research (IJMR) - Peer Reviewed Journal Volume: 7 | Issue: 4 | April 2021|| Journal DOI: 10.36713/epra2013 || SJIF Impact Factor 2021: 8.047 || ISI Value: 1.188

The effect of Public Health Expenditure on Health status annual basis in India Table-2 Regression Model Results (1992 to 2020)

\begin{tabular}{|c|c|c|c|c|c|c|}
\hline $\begin{array}{c}\text { Independent } \\
\text { Variables } \\
\downarrow \\
\end{array}$ & Constant & $\begin{array}{l}\text { Regression } \\
\text { Coefficient }\end{array}$ & $\begin{array}{c}\text { R-squared } \\
\text { (Goodness of } \\
\text { Fit) } \\
\end{array}$ & F- statistic & $\begin{array}{c}\text { Prob. } \\
\text { (F-statistic) }\end{array}$ & t- statistic \\
\hline Sex ratio & $\begin{array}{l}1.57 \\
1.02\end{array}$ & $\begin{array}{c}38.07 \\
-10.43\end{array}$ & 0.79 & 104.62 & 0.00 & $\begin{array}{r}24.18 \\
-10.23\end{array}$ \\
\hline IMR & $\begin{array}{l}1.16 \\
0.02\end{array}$ & $\begin{array}{c}32.73 \\
-0.19\end{array}$ & 0.77 & 87.70 & 0.00 & $\begin{array}{c}28.24 \\
-9.43\end{array}$ \\
\hline LEB & $\begin{array}{l}7.08 \\
0.11\end{array}$ & $\begin{array}{c}-43.88 \\
1.02\end{array}$ & 87.70 & 0.76 & 0.00 & $\begin{array}{c}-6.20 \\
9.37\end{array}$ \\
\hline CDR & $\begin{array}{l}3.19 \\
0.41\end{array}$ & $\begin{array}{l}46.14 \\
-3.07\end{array}$ & 0.68 & 56.61 & 0.00 & $\begin{array}{l}14.45 \\
-7.52\end{array}$ \\
\hline CBR & $\begin{array}{l}2.33 \\
0.10\end{array}$ & $\begin{array}{l}43.65 \\
-0.92\end{array}$ & 0.76 & 85.76 & 0.00 & $\begin{array}{l}18.73 \\
-9.26\end{array}$ \\
\hline Hospitals & $\begin{array}{l}1.69 \\
7.73\end{array}$ & $\begin{array}{l}16.64 \\
27.89\end{array}$ & 0.33 & 13.01 & 0.00 & $\begin{array}{l}9.83 \\
3.61\end{array}$ \\
\hline Hospital Beds & $\begin{array}{l}3.77 \\
3.71 \\
\end{array}$ & $\begin{array}{c}28.28 \\
-5.94\end{array}$ & 0.09 & 2.57 & 0.12 & $\begin{array}{r}7.50 \\
-1.60\end{array}$ \\
\hline Doctors & $\begin{array}{l}4.00 \\
0.05 \\
\end{array}$ & $\begin{array}{c}9.37 \\
21.52 \\
\end{array}$ & 0.68 & 57.77 & 0.00 & $\begin{array}{l}5.33 \\
7.60 \\
\end{array}$ \\
\hline Literacy & $\begin{array}{l}4.00 \\
0.05\end{array}$ & $\begin{array}{c}-21.84 \\
0.54\end{array}$ & 0.82 & 122.49 & 0.00 & $\begin{array}{l}-5.46 \\
11.07\end{array}$ \\
\hline
\end{tabular}

Source: Computed by Author Using E-views Software

The above table- 2 shows the effect of the dependent variable PHECP on all remain variables. It is visible that the dependent variable which is affected on all variables except one that is hospital beds per 1000 people. Because of hospital beds per 1000 people, remain all variables are having significant values that are less than $5 \%$. These are the parameters in my model where regressions do not have intercepted. Residual

Group Estimation of the Regression Model

Table-3 Estimates of the Least Squares Impact of Health Status on Dependent Variable: Public Health

\begin{tabular}{|l|c|c|c|c|}
\hline \multicolumn{1}{|c|}{ Independent Variable $\downarrow$} & Coefficient & Std. Error & t-Statistic & Prob. \\
\hline Constant (C) & -446.22 & 168.04 & -2.66 & 0.02 \\
\hline Sex Ratio & 12.39 & 17.82 & 0.70 & 0.50 \\
\hline Infant Mortality Rate & 0.48 & 0.45 & 1.08 & 0.29 \\
\hline Life Expectancy at Birth & 3.81 & 1.93 & 1.97 & 0.06 \\
\hline Crude Death Rate & 3.13 & 2.34 & 1.34 & 0.20 \\
\hline Crude Birth Rate & 1.19 & 1.34 & 0.89 & 0.38 \\
\hline Hospitals Served per '000 People & 5.01 & 7.08 & 0.71 & 0.49 \\
\hline Hospital Beds Served per 000 people & -0.79 & 2.19 & -0.36 & 0.72 \\
\hline Doctors Served per '000 people & 9.23 & 7.91 & 1.17 & 0.26 \\
\hline Literacy Rate & 1.46 & 0.81 & 1.80 & 0.09 \\
\hline R-squared & 0.88 & Mean dependent variable & 22.33 \\
\hline Adjusted R-squared & 0.82 & S.D. dependent variable & 3.92 \\
\hline S.E. of regression & 1.64 & Akaike info criterion & 4.10 \\
\hline Sum squared resid & 51.27 & Schwarz criterion & 4.57 \\
\hline Log likelihood & -49.41 & Hannan-Quinn criterion & 4.24 \\
\hline F-statistic & 15.61 & Durbin-Watson statistic & 1.65 \\
\hline Prob (F-statistic) & 0.00 & Included observations: 29 & \\
\hline Sorce Contion
\end{tabular}

Source: Computed by Author Using E-views Software standard error is 1.57 on 29 observation of freedom Rsquared is 0.794858 , F-statistic is 104.62 and t-statistic is 24.17 to -10.22 due to $\mathrm{p}$-value is $0.0 \%$ in sex ratio.

These are the coefficients of my parameters. The average value for dependent when independent equal to zero. This interpretation changes for categorical variables and some variable transformations.

\section{Expenditure (1992-2020)}

Source: Computed by Author Using E-views Software 
In this model, public health expenditure in the current price is the dependent variable and health care status is the independent variable. Here the components of health status are Sex Ratio, Infant Mortality Rate, Life Expectancy at Birth, Crude Death Rate, Crude Birth Rate, Hospitals Served per '000 People, Hospital Beds Served per '000 people, Doctors Served per '000 people, and Literacy Rate. If the sex ratio increase by 1 unit then the public health expenditure in the current price increases by $12.39 \%$ units keeping other factors remain constant. If IMR decreases by 1 unit then the public health expenditure in the current price is $0.48 \%$ units keeping other factors remain constant. Every model having the chances of error with their coefficient (prob. value) is $0.01 \%$. Before the interpreted criteria will be high and low. The level of call is the significance with the mostly $5 \%$ is considered. If the pvalue is greater than $5 \%$ or 0.05 it means chances are high and we will not consider the regression result for a particular variable. And if a chance of error or prob. value is less than $5 \%$ or 0.05 it means regression results are considerable and the variable is significant.

So, if t-Statistic is calculated with $\mathrm{t}$ tabulated, where, if $\mathrm{t}$-calculated is greater than t-tabulated it means reject $\mathrm{H}_{0}$ and variable is significant. F-Statistic shows the combined effect on all independent variable on a dependent variable on the dependent variable. If probabilistic Statistics is greater than $5 \%$ or 0.05 it means the combined effect is significant or considerable. The Prob. (F-statistic) is 0.000001 is less than $5 \%$ there is a significant variable of the dependent variable and independent variable. R-squared and Adjusted R-squared are forecasting this is the exploratory forecasting power of the model so both are near to $1 \%$ the value is near zero to 1 it means 0.88 and $0.82 \%$. Independent variables will forecast the 88.08 per cent true value of a dependent variable.

Table-4 Residual Check-in Regression Model

\begin{tabular}{|c|c|c|c|}
\hline Year & Actual & Fitted & Residual \\
\hline 1992 & 17.65 & 17.40 & 0.25 \\
\hline 1993 & 17.88 & 17.59 & 0.29 \\
\hline 1994 & 18.28 & 18.47 & -0.19 \\
\hline 1995 & 18.68 & 18.72 & -0.04 \\
\hline 1996 & 18.99 & 19.11 & -0.12 \\
\hline 1997 & 20.25 & 20.06 & 0.19 \\
\hline 1998 & 17.98 & 20.51 & -2.53 \\
\hline 1999 & 20.98 & 19.37 & 1.61 \\
\hline 2000 & 20.68 & 18.74 & 1.94 \\
\hline 2001 & 18.87 & 18.55 & 0.32 \\
\hline 2002 & 18.16 & 18.96 & -0.80 \\
\hline 2003 & 18.71 & 19.97 & -1.26 \\
\hline 2004 & 17.98 & 18.43 & -0.45 \\
\hline 2005 & 20.12 & 21.04 & -0.92 \\
\hline 2006 & 20.51 & 20.55 & -0.04 \\
\hline 2007 & 20.89 & 21.46 & -0.57 \\
\hline 2008 & 22.63 & 23.76 & $\begin{array}{l}-1.13 \\
\end{array}$ \\
\hline 2009 & 25.61 & 23.88 & 1.73 \\
\hline 2010 & 26.21 & 25.34 & 0.87 \\
\hline 2011 & 28.87 & 24.89 & 3.98 \\
\hline 2012 & 27.98 & 26.98 & 1.00 \\
\hline 2013 & 23.07 & 25.97 & -2.90 \\
\hline 2014 & 23.66 & 24.95 & -1.29 \\
\hline 2015 & 25.64 & 25.02 & 0.62 \\
\hline 2016 & 26.84 & 26.33 & 0.51 \\
\hline 2017 & 27.13 & 27.52 & $\begin{array}{l}-0.39 \\
\end{array}$ \\
\hline 2018 & 27.78 & 29.04 & -1.26 \\
\hline 2019 & 28.52 & 28.20 & 0.32 \\
\hline 2020 & 27.13 & 26.87 & 0.26 \\
\hline
\end{tabular}


The above table shows that Table-4 Residual Check-in Regression Model. Here the year from 1992-2020 has been shown regarding residuals. Moreover, the residuals are deviating to both the side, like towards positive and negative also. In total, they become zero if we add them.

\section{Figure-1 Residual Check-in Regression Model Trend Line}

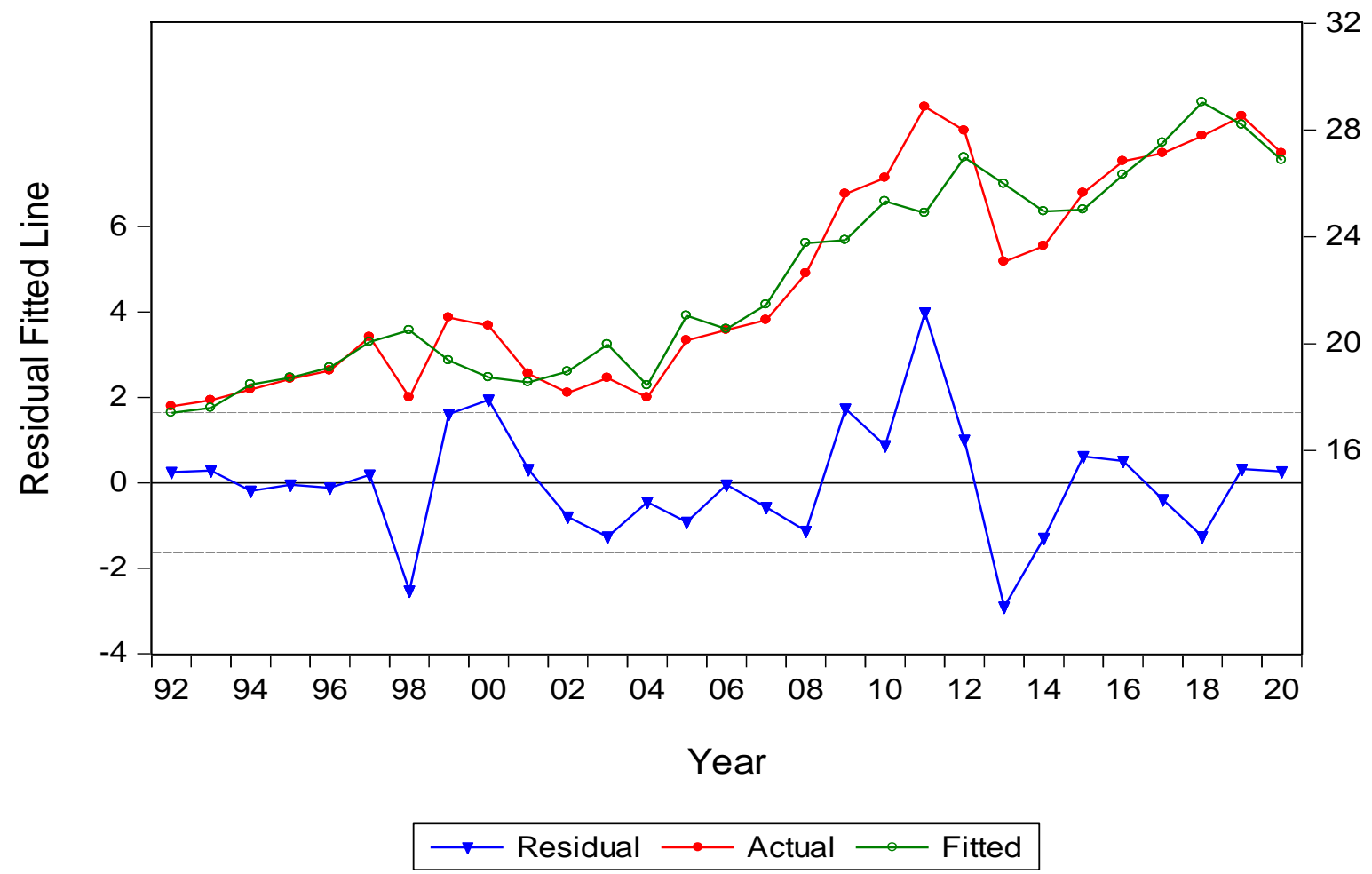

Source: Computed by Author Using E-views Software

Figure-1 shows the trend line of checking the residuals in the regression model. Where the blue line shows the residuals and the red line shows the actual values of the coefficient and the black line shows the fitted value of the coefficient. Here the deviation is not huge but a little bit of deviation is there in this model. The residual line of PHECP. Here also the deviation is a little bit less. But still in between fluctuation is there.

\section{Residual serial correlated or not}

However, the diagnostic test for the Leastsquares estimates revealed some shortfalls. Thus, there were the presences of serial correlation as shows by the LM test while no Heteroskedasticity was found. While the Breusch-Pagan-Geoffrey (BPG) test could not reject the null hypothesis of no Heteroskedasticity (Fstatistic $=2.01, \mathrm{p}$-value $=0.16, \mathrm{Obs}^{*} \mathrm{R}$-squared $=5.55$ and $\mathrm{p}$-value Chi-Square $=0.06$ ).

Table-5 Breusch-Godfrey Serial Correlation LM Test due to Dependent Variable: Residual Least Squares (1992-2020)

\begin{tabular}{|c|c|c|c|c|}
\hline F-statistic & 2.01 & \multicolumn{2}{|c|}{ Prob. F(2,17) } & 0.16 \\
\hline Obs*R-squared & 5.55 & \multicolumn{2}{|c|}{ Prob. Chi-Square(2) } & 0.06 \\
\hline \multicolumn{5}{|c|}{ Pre sample missing value lagged residuals set to zero. } \\
\hline Independent Variable $\downarrow$ & Coefficient & Std. Error & t-Statistic & Prob. \\
\hline Constant (C) & 10.43 & 173.82 & 0.06 & 0.95 \\
\hline Sex Ratio & 0.80 & 17.02 & 0.05 & 0.96 \\
\hline Infant Mortality Rate & -0.04 & 0.43 & -0.10 & 0.92 \\
\hline
\end{tabular}


ISSN (Online): 2455-3662

EPRA International Journal of Multidisciplinary Research (IJMR) - Peer Reviewed Journal Volume: 7 | Issue: 4 | April 2021|| Journal DOI: 10.36713/epra2013 || SJIF Impact Factor 2021: 8.047 || ISI Value: 1.188

\begin{tabular}{|l|c|c|c|c|}
\hline Life Expectancy at Birth & -0.22 & 2.01 & -0.11 & 0.92 \\
\hline Crude Death Rate & -0.20 & 2.37 & -0.08 & 0.93 \\
\hline Crude Birth Rate & 0.08 & 1.49 & 0.05 & 0.96 \\
\hline Hospitals Served Per '000 population & -7.64 & 7.74 & -0.99 & 0.34 \\
\hline Hospital Beds Served Per `000 population & -0.95 & 2.17 & -0.44 & 0.67 \\
\hline Doctors Served Per average population & 1.36 & 7.75 & 0.18 & 0.86 \\
\hline Literacy Rate & 0.07 & 0.77 & 0.09 & 0.93 \\
\hline RESID (-1) & 0.26 & 0.27 & 0.99 & 0.34 \\
\hline RESID (-2) & -0.51 & 0.29 & -1.75 & 0.10 \\
\hline R-squared & 0.19 & Mean dependent variable & 1.96 \\
\hline Adjusted R-squared & -0.33 & S.D. dependent variable & 1.35 \\
\hline S.E. of regression & 1.56 & Akaike info criterion & 4.02 \\
\hline Sum squared residual & 41.45 & Schwarz criterion & 4.59 \\
\hline Log likelihood & -46.33 & Hannan-Quinn criterion & 4.20 \\
\hline F-statistic & 0.37 & Durbin-Watson statistic & 2.35 \\
\hline Probability (F-statistic) & 0.95 & Included observations: 29 \\
\hline
\end{tabular}

Source: Computed by Author Using E-views Software

The LM test rejected the null hypothesis of no serial correlation $(\mathrm{F}=0.37$, p-value $=0.95$, Prob. (F-statistic) thus, the serial correlation was present in the residuals whereas Heteroskedasticity was absent. P-value is 0.06 it is more than $5 \%$ so meaning that is not reject the null hypothesis rather we accept the null hypothesis. The null hypo is residual is serial not correlated this model is not serial correlated this not correlated.

\section{Residual is Heteroskedasticity or not}

The normality test also suggests that the variables were distributed normally since the null hypothesis of normal distributed could not be rejected (Jacque-Bera $=3.74 ; p=0.15$ ). As already indicated, the presence of serial correlation necessitated the use of Heteroskedasticity Test: Breusch-Pagan-Godfrey estimator to remedy the serial correlation problem (below table-6)

Table-6 Heteroskedasticity Test: Breusch-Pagan-Godfrey

\begin{tabular}{|c|c|c|c|c|}
\hline F-statistic & 2.73 & \multicolumn{2}{|l|}{ Prob. F $(9,19)$} & 0.03 \\
\hline Obs*R-squared & 16.34 & \multicolumn{2}{|c|}{ Prob. Chi-Square(9) } & 0.06 \\
\hline Scaled explained SS & 12.22 & \multicolumn{2}{|c|}{ Prob. Chi-Square(9) } & 0.20 \\
\hline \multicolumn{5}{|c|}{ Method: Least Squares of Dependent Variable: RESID^2 } \\
\hline Independent Variable $\downarrow$ & Coefficient & Std. Error & t-Statistic & Prob. \\
\hline Constant (C) & -433.12 & 275.55 & -1.57 & 0.13 \\
\hline Sex Ratio & 55.68 & 29.22 & 1.91 & 0.07 \\
\hline Infant Mortality Rate & -0.25 & 0.73 & -0.34 & 0.74 \\
\hline Life Expectancy at Birth & 2.37 & 3.17 & 0.75 & 0.46 \\
\hline Crude Death Rate & 2.38 & 3.83 & 0.62 & 0.54 \\
\hline Crude Birth Rate & 0.98 & 2.19 & 0.44 & 0.66 \\
\hline Hospitals Served Per '000 population & -38.02 & 11.61 & -3.27 & 0.00 \\
\hline Hospital Beds Served '000 population & 1.22 & 3.59 & 0.34 & 0.74 \\
\hline Doctors Served Per average people & 7.40 & 12.97 & 0.57 & 0.58 \\
\hline Literacy Rate & 2.10 & 1.33 & 1.58 & 0.13 \\
\hline R-squared & 0.56 & \multicolumn{2}{|c|}{ Mean dependent variable } & 1.77 \\
\hline Adjusted R-squared & 0.36 & \multicolumn{2}{|c|}{ S.D. dependent variable } & 3.36 \\
\hline S.E. of regression & 2.69 & \multicolumn{2}{|c|}{ Akaike info criterion } & 5.09 \\
\hline Sum squared residual & 137.84 & \multicolumn{2}{|c|}{ Schwarz criterion } & 5.56 \\
\hline Log likelihood & -63.75 & \multicolumn{2}{|c|}{ Hannan-Quinn criterion } & 5.23 \\
\hline F-statistic & 2.73 & \multirow{2}{*}{\multicolumn{2}{|c|}{\begin{tabular}{|l} 
Durbin-Watson statistic \\
Included observations: 29
\end{tabular}}} & 3.02 \\
\hline Probability (F-statistic) & 0.03 & & & \\
\hline
\end{tabular}


Further, the diagnostics revealed some degree of multicolinearity among the variables as shown by the correlation matrix of the estimated coefficients. Heteroskedasticity Test: Breusch-Pagan-Godfrey is obs. R-square and corresponding p-value is $0.06 \%$ which is more than $5 \%$ meaning that cannot reject the null hypothesis rather than accept the null hypothesis. The null hypothesis is residual is not Heteroskedasticity meaning that is homo sadistic. Because this model residual not rather we are happy about the model. Because we could not reject the null hypothesis residual is not Heteroskedasticity.

Figure-2 Normality Test of Residual should normally distribute good regression model

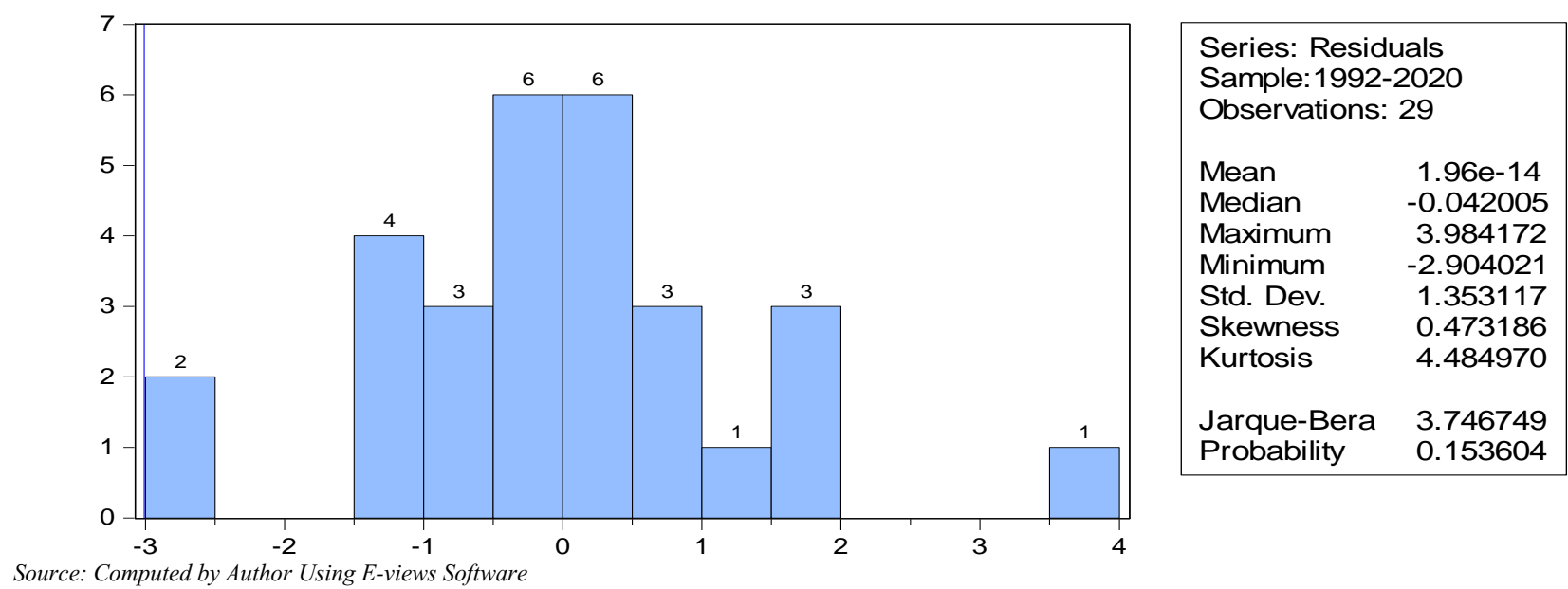

Here, the value of Jarque-Bera is $3.74 \%$ and the $\mathrm{p}$ value is $0.15 \%$ which is more than $5 \%$. Hence we cannot reject $\mathrm{H}_{0}$ rather we accept the null hypothesis. Means residual is normally distributed. So overall the model is a good fit.

$\mathrm{PHECP}=\mathrm{C}(1)+\mathrm{C}(2) * \mathrm{SR}+\mathrm{C}(3) * \mathrm{CBR}+\mathrm{C}(4) * \mathrm{CDR}+$ $\mathrm{C}(5) *$ Doctors Served Per Average people +

$\mathrm{C}(6)^{*}$ Hospital Beds Served Per '000 people +

$\mathrm{C}(7)^{*}$ Hospitals Served Per Average population +

$\mathrm{C}(8) * \mathrm{IMR}+\mathrm{C}(9) * \mathrm{LEB}+\mathrm{C}(10) * \mathrm{LR}$
The regression model has specified Substituted Coefficients:

PHECP $=-446.22+12.39 * \mathrm{SR}+1.19 * \mathrm{CBR}+$

$3.13 * \mathrm{CDR}+9.23 *$ Doctors Served per Average people - 0.79* Hospital Beds Served Per '000 people $+5.01 *$

Hospitals Served per Average population $+0.48 *$ IMR

$+3.81 * \mathrm{LEB}+1.46 * \mathrm{LR}$

...... (10.2)

Table-7 Public Health Expenditure at Current Prices in India

Dependent Variable: PHECP

Method: Least Squares

Sample: 1992-2020

\begin{tabular}{|l|c|c|c|c|}
\hline Variable & Coefficient & Std. Error & t-Statistic & Prob. \\
\hline C & -446.22 & 168.04 & -2.66 & 0.02 \\
\hline Sex Ratio & 12.39 & 17.82 & 0.70 & 0.50 \\
\hline Crude Birth Rate & 1.19 & 1.34 & 0.89 & 0.38 \\
\hline Crude Death Rate & 3.13 & 2.34 & 1.34 & 0.20 \\
\hline Doctors Served Per Average people & 9.23 & 7.91 & 1.17 & 0.26 \\
\hline Hospital Beds Served Per '000 people & -0.79 & 2.19 & -0.36 & 0.72 \\
\hline Hospitals Served Per Average people & 5.01 & 7.08 & 0.71 & 0.49 \\
\hline Infant Mortality Rate & 0.48 & 0.45 & 1.08 & 0.29 \\
\hline Life Expectancy at Birth & 3.81 & 1.93 & 1.97 & 0.06 \\
\hline
\end{tabular}


ISSN (Online): 2455-3662

EPRA International Journal of Multidisciplinary Research (IJMR) - Peer Reviewed Journal Volume: 7 | Issue: 4 | April 2021|| Journal DOI: 10.36713/epra2013 || SJIF Impact Factor 2021: 8.047 || ISI Value: 1.188

\begin{tabular}{|c|c|c|c|c|}
\hline Literacy Rate & 1.46 & 0.81 & 1.80 & 0.09 \\
\hline R-squared & 0.88 & \multicolumn{2}{|c|}{ Mean dependent var } & 22.33 \\
\hline Adjusted R-squared & 0.82 & \multicolumn{2}{|c|}{ S.D. dependent var } & 3.92 \\
\hline S.E. of regression & 1.64 & \multicolumn{2}{|c|}{ Akaike info criterion } & 4.10 \\
\hline Sum squared residual & 51.27 & \multicolumn{2}{|c|}{ Schwarz criterion } & 4.57 \\
\hline Log-likelihood & -49.41 & \multicolumn{2}{|c|}{ Hannan-Quinn criter. } & 4.24 \\
\hline F-statistic & 15.61 & \multicolumn{2}{|c|}{ Durbin-Watson stat } & 1.65 \\
\hline Probability (F-statistic) & 0.00 & \multicolumn{3}{|c|}{ Included observations: 29} \\
\hline
\end{tabular}

Source: Computed by Author Using E-views Software

Table-8 Summary Regression Statistic's of the Effect of Public Health Expenditure with Current Price on Health Status

\begin{tabular}{|c|c|c|c|c|}
\hline Variables & Coefficient & Standard Error & t-value & Probability \\
\hline \multicolumn{5}{|c|}{ Residual is Serial Correlated and Heteroskedasticity or not } \\
\hline \multirow[t]{2}{*}{ Constant (C) } & 10.43 & 173.82 & 0.06 & 0.95 \\
\hline & -433.12 & 275.55 & -1.57 & 0.13 \\
\hline \multirow{2}{*}{ Sex Ratio } & 0.80 & 17.02 & 0.05 & 0.96 \\
\hline & 55.68 & 29.22 & 1.91 & 0.07 \\
\hline \multirow{2}{*}{ Infant Mortality Rate } & -0.04 & 0.43 & -0.10 & 0.92 \\
\hline & -0.25 & 0.73 & -0.34 & 0.74 \\
\hline \multirow{2}{*}{ Life Expectancy at Birth } & -0.22 & 2.01 & -0.11 & 0.92 \\
\hline & 2.37 & 3.17 & 0.75 & 0.46 \\
\hline \multirow{2}{*}{ Crude Death Rate } & -0.20 & 2.37 & -0.08 & 0.93 \\
\hline & 2.38 & 3.83 & 0.62 & 0.54 \\
\hline \multirow{2}{*}{ Crude Birth Rate } & 0.08 & 1.49 & 0.05 & 0.96 \\
\hline & 0.98 & 2.19 & 0.44 & 0.66 \\
\hline \multirow[b]{2}{*}{ Hospitals Served Per '000 people } & -7.64 & 7.74 & -0.99 & 0.34 \\
\hline & -38.02 & 11.61 & -3.27 & 0.00 \\
\hline \multirow{2}{*}{$\begin{array}{l}\text { Hospital Beds Served Per '000 } \\
\text { people }\end{array}$} & -0.95 & 2.17 & -0.44 & 0.67 \\
\hline & 1.22 & 3.59 & 0.34 & 0.74 \\
\hline \multirow{2}{*}{ Doctors Served Per '000 people } & 1.36 & 7.75 & 0.18 & 0.86 \\
\hline & 7.40 & 12.97 & 0.57 & 0.58 \\
\hline \multirow{2}{*}{ Literacy Rate } & 0.07 & 0.77 & 0.09 & 0.93 \\
\hline & 2.10 & 1.33 & 1.58 & 0.13 \\
\hline
\end{tabular}

Source: Author own Estimation. (Note: *represent 10\% level of significance, while ${ }^{*}$ stands for $5 \%$ level of significance)

Residual shall be checking Jarque-Bera and probability how much $p$ vale is $0.15 \%$ is the more than $5 \%$ so we cannot null hypothesis. The null hypothesis is residual are normality distributed here p-value is more than 5\% so we cannot the reject null hypothesis rather than accept the null hypothesis. Residual are normal distribution the serial are normal distribution.

\section{Empirical Result}

The number of the equation was first estimated with the ordinary least squares (OLS) techniques. However, because of the possibility of reverse causality or joint determination of health status and public health expenditure, it was re-estimated using the two-stage least squares (2SLS) method. The result of the OLS is presented and discussed first and this is compared with that of the 2SLS.
Ordinary Least Squares (OLS) Regression: Factors affecting Health care Status

Table-9 below contains the estimates for the OLS model of calculation of the number of equations. The first column under each of the Sex ratios is the result of the simple version of equation-10.1 (3.21), which does contain the Health status variable, is significant. The result of the simple version for IMR indicates that there is a negative relationship between PHECP, which is in line with theoretical expectation, the coefficient of health status is however significant. Although the coefficient of health expenditure is significant, it carries the right sign. The two variable included in the model explains $(3.21 \%)$ and $(0.79 \%)$ of the variation in infant mortality rate. 
ISSN (Online): 2455-3662

EPRA International Journal of Multidisciplinary Research (IJMR) - Peer Reviewed Journal

Volume: 7 | Issue: 4 | April 2021|| Journal DOI: 10.36713/epra2013 || SJIF Impact Factor 2021: 8.047 || ISI Value: 1.188

Table-9 Ordinary Least Squares Regression Results

\begin{tabular}{|c|c|c|c|c|c|c|c|c|c|}
\hline \multirow{2}{*}{$\begin{array}{c}\begin{array}{c}\text { Dependent } \\
\text { Variables } \\
\rightarrow\end{array} \\
\text { Independen } \\
\text { t Variables } \\
\text { Significant } \\
\text { Variables } \\
\downarrow\end{array}$} & \multicolumn{9}{|c|}{ Public Health Expenditure with Current Price on Health Status } \\
\hline & $\begin{array}{c}\text { Eq.1.1. } \\
1\end{array}$ & $\begin{array}{c}\text { Eq.2.1. } \\
1\end{array}$ & $\begin{array}{c}\text { Eq.3.1. } \\
1\end{array}$ & $\begin{array}{c}\text { Eq.4.1. } \\
1\end{array}$ & $\begin{array}{c}\text { Eq.5.1. } \\
1\end{array}$ & $\begin{array}{c}\text { Eq.6.1. } \\
1\end{array}$ & $\begin{array}{c}\text { Eq.7.1. } \\
1\end{array}$ & $\begin{array}{c}\text { Eq.8.1. } \\
1\end{array}$ & $\begin{array}{c}\text { Eq.9.1. } \\
1\end{array}$ \\
\hline Sex Ratio & $\begin{array}{c}3.21 \\
(0.00)\end{array}$ & & & & & & & & \\
\hline $\begin{array}{c}\text { Infant } \\
\text { Mortality } \\
\text { Rate }\end{array}$ & & $\begin{array}{l}-4.00 \\
(0.00)\end{array}$ & & & & & & & \\
\hline $\begin{array}{c}\text { Life } \\
\text { Expectancy } \\
\text { at Birth }\end{array}$ & & & $\begin{array}{c}\mathbf{0 . 7 5} \\
(0.00)\end{array}$ & & & & & & \\
\hline $\begin{array}{c}\text { Crude Death } \\
\text { Rate }\end{array}$ & & & & $\begin{array}{l}\mathbf{- 0 . 2 2} \\
(0.00)\end{array}$ & & & & & \\
\hline $\begin{array}{c}\text { Crude Birth } \\
\text { Rate }\end{array}$ & & & & & $\begin{array}{l}\mathbf{- 0 . 8 3} \\
(0.00)\end{array}$ & & & & \\
\hline $\begin{array}{c}\text { Hospitals } \\
\text { Served Per } \\
\text { '000 people }\end{array}$ & & & & & & $\begin{array}{c}\mathbf{0 . 3 0} \\
(0.45)\end{array}$ & & & \\
\hline $\begin{array}{c}\text { Hospital } \\
\text { Beds Served } \\
\text { Per '000 } \\
\text { people }\end{array}$ & & & & & & & $\begin{array}{l}\mathbf{- 0 . 0 1} \\
(0.12)\end{array}$ & & \\
\hline $\begin{array}{c}\text { Doctors } \\
\text { Served Per } \\
\text { ‘000 people }\end{array}$ & & & & & & & & $\begin{array}{c}\mathbf{0 . 0 3} \\
(0.28)\end{array}$ & \\
\hline Literacy Rate & & & & & & & & & $\begin{array}{c}1.52 \\
(0.00) \\
\end{array}$ \\
\hline Constant (C) & 3.21 & 143.58 & 48.08 & 12.70 & 41.60 & -0.06 & 1.33 & -0.10 & 47.92 \\
\hline $\begin{array}{l}\text { Adjusted R- } \\
\text { squared }\end{array}$ & 0.79 & 0.76 & 0.76 & 0.68 & 0.75 & 0.30 & 0.05 & 0.67 & 0.82 \\
\hline
\end{tabular}

Above the table, we bring in the issue of efficacious public health expenditure at current prices. To do this, we interacted with PHECP and also include the regressors to capture the direct effect of health status. This result is presented in the five, six and sevencolumn as mentioned earlier. For the hospital, Beds and Doctors have the expected sign but its coefficient is insignificant. Health expenditure in this version is significant and in the right direction contrary to what obtains under the simple version. The coefficient of health expenditure indicates that a negative per cent increase in PHECP is associated with a negative reduction in CDR, CBR, IMR but the coefficient is significant. The OLS results presented above is based on the assumption that health expenditure is exogenous.
It has been noted by the earlier researcher that both public health expenditure and health status could jointly be determined. There is also the possibility of reverse causation.

\section{Limitation of the study}

Any Econometric study will have many limitations, even when the models are rigorously specified. Our study also may suffer from such limitations which are mentioned below.

1. There may be some important independent variables that are not included in the model, which may deprive the model of its practical significance.

2. The models are selected in this study based on the statistical criterion of explanatory power. Some models 
having higher explanatory power may not have sound theoretical underpinning.

3. The conclusion derived only for the Indian context for the particular reference period 1992 to 2020. Therefore generalizations based on the conclusions derived here may not be valid for the other countries or the other period.

\section{Findings}

Concerning the Dependent Variable of public Health expenditure at Current Prices (PHECP) incurred on independent variables of health care Status in India, the analysis reveals the following important findings: Estimates of the Least Squares Regression Result of the Effect of Public Health Expenditure on Sex Ratio (1992-2020). The public health expenditure at current prices in the country, irrespective of Sex ratio has decreased gradually over the period from 1992 to 2020 with a PHECP of $\mathbf{1 7 . 5 5}$ per cent Coefficient of Variation and with Sex ratio growth rate of 1.51 per cent. Estimates of the Least Squares impact of Public Health Expenditure on Infant Mortality Rate (19922020) Under IMR and Public Health expenditure at current prices, public Health expenditure has seen an increase from Rs. 17.65 crore in 1992 to that of Rs. 27.13 crore in the year 2020. Under Family welfare, the public health expenditure has increased from Rs.22.33 crore in 2000-01 to that of Rs. 8859.55 crore in the year 2010-11.

The percentage of public expenditure incurred on health to the total public expenditure incurred in the country has more or less remained stagnant during the period 2000-01 to 2010-11. On average, it remained at 0.39 per cent. The per capita public expenditure on the health sector in India increased from Rs.24.26 in 200001 to Rs.157.18 during the year 2010-11. On average, the per capita expenditure on the health sector in India remained at Rs.72.35. There was a slight increase in the percentage share of health expenditure to the total expenditure on social services. It increased from 13.65 per cent in 2000-01 to that of 14.46 per cent during the year 2010-11. The percentage share of health expenditure constituted around 0.13 per cent of the GDP of the country in 2000-01. It saw a mere increase of 0.13 per cent during the year 2010-11. Besides this revealing trend, The Government of India has set the target of increasing the government health spending to 2-3 per cent of the country's GDP over the next five years, but it seems to be an uphill task to be achieved.

\section{Suggestions}

Based on the above findings, the following suggestions need attention. If 2-3 per cent of India's GDP should constitute health expenditure in the country, then the allocations in the budget for the health sector needs to be increased sufficiently. Apart from that, the Government should take precautionary measures concerning capital expenditure incurred on the health sector in India, because it has witnessed a negative growth rate under capital account on health sector during the year 1992 to 2020. As per the National Health Accounts, public health expenditure accounts for 26.7 per cent of the total health expenditure in India. Apart from that the public health expenditure to the total public expenditure in the country is dwindling from 0.30 to 0.40 per cent. Therefore high priority to the health sector should be provided in the Union Budget to increase the share of public expenditure on health.

\section{Policy Recommendation}

Indian Government should adopt policies that will increase public health expenditure in the health sector. This implies that increasing public health expenditure would be greatly helpful in moving Indian toward the SDGs target for health, although this is only a necessary condition in achieving those goals. This is suggesting that government should endeavour to improve income equality among citizens through its redistribution role to afford an increasing portion of the population access to larger income that will finance health care, though its effect is not very significant.

\section{CONCLUSION}

This study has examined the way of trend through which the health care expenditure is being occurred in India and what is the pattern of this health care expenditure. For many developing nations, there must be proper health care expenditure for being better health status of the nation so that the nation can grow properly. The nation where the health status is well the people will be getting the proper health facilities along with proper other facilities regarding financial matter then definitely the nation will grow consistently.

More Focus is required on Expanding Public Sector Healthcare in the Economic Survey 2019-20 reports that around 74 per cent of outpatient care and 65 per cent of hospitalisation care is provided through the private sector in urban India which highlights the need for expanding and strengthening public healthcare system in the country. The Economic Survey also calls for continued emphasis on the National Health Mission (NHM), citing its important role in minimizing inequity in healthcare access in the country. Under NHM, allocation increased by 20.45 per cent from 2020-21.

\section{REFERENCES}

1. Grossman, M. (1972). On the Concept of Health Capital and the Demand for Health. The Journal of Political Economy, 80(2):223-255. 
2. Kenneth, J. A. (1963). Uncertainty and the Welfare Economics of Medical Care. American Economic Review, 53(5):941-973.

3. Andersen, R. M. (1995). Revisiting the Behavioral Model and access to medical care: Does it matter?. Journal of Health and Social Behavior, 36(1):1-10.

4. Burns, L. R. \& Wholey, D. R. (1992). The impact of physician characteristics in conditional choice models for hospital care. Journal of Health Economics, Elsevier, 11(1):43-62.

5. Feldstein, M. S. (1973). The Welfare Loss of Excess Health Insurance. Journal of Political Economy, University of Chicago Press, 81(2):251-280.

6. Mahendra, P. A. \& Rout, B. (2007). Determinants of Health Care Expenditure in Odisha, Problems and Prospects. IOSR Journal of Humanities and Social Science (IOSR-JHSS), 23(06): 19-26.

7. Ahmed, S. M., Tomson, G., Petzold, M. \& Kabir, Z. N. (2005). Socioeconomic status overrides age and gender in determining health-seeking behaviour in rural Bangladesh. Bulletin of the World Health Organization, 83(2):109-17.

8. Alderman, $\boldsymbol{H}$. \& Gertler, $\boldsymbol{P}$. (1997). Family resources and gender differences in human capital investments: The demand for children's medical care in Pakistan. The Johns Hopkins University Press. 1(1):1231-248.

9. Deaton, A., Ruiz-Castillo, J. \& Thomas, D. (1989). The influence of household composition on household expenditure pattern: Theory and Spanish evidence. Journal of Political Economy, 97(1):179-200.

10. Iyer, A., Sen, G. \& George, A. (2007). The dynamics of gender and class in access to health care: Evidence from rural Karnataka, India. International Journal of Health Services, 37(3):537-54.

11. Mumtaz, Z. \& Salway, S. (2005). I never go anywhere: Extricating the links between women's mobility and uptake of reproductive health services in Pakistan. Social Science Medicine, 60(8):751-765.

12. Parker, S. W. \& Wong, R. (1997). Household income and health care expenditures in Mexico. Health Policy, 40(3):237-55.

13. Pollack, R. A. \& Wales, T. J. (1981). Demographic variables in demand analysis. Econometrica, 49(1):533-59.

14. Ravindran, T. K. S. \& Maceira, D. (2005). Health financing reforms: Health sector reforms and sexual and reproductive health South Africa. Women's Health Project, Parktown, 1(1):26-89.

15. Rout, H. S. (2008). Socioeconomic factors and household health expenditure: The case of Odisha. Journal of Health Management, 10(1):101-118.

16. Saha, S. \& Ravindran, T. K. S. (2002). Gender gaps in research on health services in India. Journal of Health Management, 4(2):185-214.

17. Sen, G., Iyer, A. \& George, A. (2002). Class, gender and health equity: Lessons from liberalization in India. Cambridge, MA: MIT Press, 1(1):281-311.

18. Zaidi, S. A. (1996). Gender perspectives and quality of care in underdeveloped countries: Disease, gender and conceptuality. Social Science Medicine, 43(5):721-730. 